on Science and Technology as Applied to Less Developed Countries stated that in many of these cases there is no specific type of infection.

It is well known that children in the better developed countries are growing more rapidly and there is some evidence from Scandinavia that the final heights may be increasing (Cuthbertson, 1958). The adolescent spurt, as determined by the onset of the menarche in girls and the growth spurt in both sexes, is occurring earlier. Part of it is undoubtedly due to better nutrition-gone are bow and knock knees. Regardless of the doubtful desirability of greater height for all per se, it is a factspeaking statistically of populations - that a suboptimal diet cannot be improved without a corresponding increase in the rate of growth and maturation. Conversely, poorer nutrition will be reflected in a slowing of these characteristics.

So long as the mothers' milk supply is adequate in these poorer communities the children grow as rapidly as those of well-nourished communities. It is after weaning that growth and maturation are markedly slowed down in the former.

In our discussions we should probably eliminate such ill-defined terms as 'optimal requirements' but describe those requirements which suffice to cover all the current needs of healthy children and enable them to meet both the common and the rare stresses of daily life and fulfil their genetic potential in these respects, as physiological requirements. The protein intake of a breast-fed infant is $2 \cdot 0-2 \cdot 5 \mathrm{~g} / \mathrm{kg}$ daily, but mixtures based on cow's milk commonly provide $3-4 \mathrm{~g} / \mathrm{kg}$ and there is much controversy as to which level is more satisfactory; and if we consider the mineral intake there is roughly the same degree of difference. This difference is bound up with the widely different growth rates of the calf and the human baby. Holt (I 959) has suggested that the only way to find out the better system for the human infant would be to compare the different regimes with the ability to withstand the challenges to which the child is subject, both in infancy and later life, which has never been done.

\title{
REFERENCES
}

Cadogan, W. (1750). Essay on Nursing and Management of Children, $4^{\text {th }}$ ed. London: Roberts.

Cheadle, W. B. (1889). The Artificial Feeding and Food Disorders of Infants. London: Smith, Elder \& Co.

Cuthbertson, D. P. (1958). Proc. Borden Centennial Symposium on Nutrition. IV. The Adolescent, p. 38. New York: The Borden Company.

Drummond, J. C. \& Wilbraham, A. (1958). The Englishman's Food, 2nd ed. London: Jonathan Cape. Hanway, J. (I 757). A Yournal of Eight Days Yourney. London: Ballard.

Holt, L. E. Jr. (1959). J. Pediat. 54, 496.

Scrimshaw, N. S. (1958). Proc. Borden Centennial Symposium on Nutrition. III. The Growing Child, p. 27. New York: The Borden Company.

\section{The experimental approach to some paediatric problems}

\section{By Elsie M. Widdowson, Medical Research Council Department of Experimental Medicine, University of Cambridge}

Although brilliant contributions to the respiratory physiology of the foetus and newborn animal were made by Harvey and Mayow in the 17 th century (Harvey, 
I65I; Mayow, I668, see Parsons, I950), and to the study of the development of thermal stability in the newborn by Edwards in the I 9 th century (Edwards, I824, I 832), it is only during the present century that infant physiology has developed as a study in its own right. It is now realized that the baby is not just a miniature adult, but that it differs from the adult in many important ways. The same thing is true of the newborn of other mammalian species, and studies on newborn animals have made great contributions to our knowledge about the physiology of the human baby. I am proposing to illustrate this by four examples, each showing how experimental work in newborn animals has helped to solve a paediatric problem in man.

\section{The excretion of sodium}

During the Second World War there was great enthusiasm for giving protein hydrolysates by mouth and by vein, for it was thought that this might be the ideal way of giving amino acids to starving people. Protein hydrolysates were given to adult patients suffering from various diseases, and also to babies, particularly premature babies. The babies seemed to do well for a time and gained weight, but then it was realized that the progress was not always being maintained. Some became oedematous, and some of the weight these babies had gained was evidently oedema fluid. The babies that became oedematous were mainly those that had been given preparations of amino acids made by acid hydrolysis of protein and subsequent neutralization of the mixture with sodium hydroxide.

It was shown during the early war years that newborn babies had lower clearances of sodium and chloride per $\mathrm{m}^{2}$ body surface and per $\mathrm{kg}$ body-weight than adults (McCance \& Young, I940-I). At any given concentration of $\mathrm{Na}$ and $\mathrm{Cl}$ in the serum, even when high, infants, particularly premature infants, excreted less $\mathrm{NaCl}$ in relation to water than adults. Could the retention of $\mathrm{NaCl}$, and with it water, have been the cause of the trouble after feeding with protein hydrolysates?

We turned our attention to this question experimentally in newborn piglets some years later (McCance \& Widdowson, 1957). We fed the animals by stomach tube for the first 2 days of their lives. To some we gave sow's milk and to others sow's milk to which we had added $\mathrm{NaCl}$ to make the concentration up to $0.5,0.7$ or $0.9 \%$. These are not high concentrations, and an adult would have had no difficulty in excreting the salt. Piglets, however, did not react in this way. Table I shows their weight changes, urine volumes and $\mathrm{Na}$ balances. Those having salted milk gained much more weight than the others because they retained water, and their urine volumes were correspondingly less. The newborn piglets having sow's milk alone excreted almost no $\mathrm{Na}$ in their urine; the sow's milk contained just about the right amount for the needs of the growing body. On the higher intake the piglets excreted only a fraction of the additional $\mathrm{NaCl}$. They retained water with the $\mathrm{NaCl}$, but not enough to maintain osmolar stability of the extracellular fluid, and the serum $\mathrm{Na}$ rose.

Then we made a similar study on babies (McCance \& Widdowson, r957). We added sufficient $\mathrm{NaCl}$ to the milk given to three premature babies $3^{-6}$ weeks old to make the concentration up to $0.7 \%$. There was at once a great increase in weight, and after 2 or 3 days the babies became oedematous. As soon as oedema appeared we 
Table I. Effects of giving to piglets sow's milk containing $0.9 \% \mathrm{NaCl}$

$\begin{array}{lcc} & \text { Sow's milk } & \text { Salted sow's milk } \\ \text { Gain in weight (g/kg weight at birth) } & 68 & \text { I92 } \\ \text { Urine volume (ml } / \mathrm{kg} \mathrm{24} \mathrm{h} \text { ) } & 2 \mathrm{I} 9 & 67 \\ \mathrm{Na} \text { intake (m-equiv. } / \mathrm{kg} \mathrm{24} \mathrm{h} \text { ) } & 4 \cdot 6 & 4 \mathrm{I} \cdot 7 \\ \mathrm{Na} \text { excretion (m-equiv./kg 24 h) } & 0 \cdot \mathrm{I} & 6 \cdot 9 \\ \text { Serum Na (m-equiv./1.) } & \mathrm{I} 40 & \mathrm{I} 62\end{array}$

withdrew the salt. The babies excreted the salt over the next few days, their weights fell, and then proceeded along their original course.

We concluded that these experiments proved the inefficiency of the baby's and piglet's kidneys in excreting salt. It may be so, but there is a further consideration. Babies having breast milk receive enough $\mathrm{Na}$ in their natural food to provide them daily with about $130 \mathrm{mg} \mathrm{Na} / \mathrm{kg}$, which is equivalent to about $9 \mathrm{~g} \mathrm{NaCl}$ for a $70 \mathrm{~kg}$ man. Breast milk cannot be considered a low-salt diet; yet on it babies manage to maintain osmolar stability and they excrete in the urine $100 \mathrm{mg} \mathrm{Na} / \mathrm{kg}$ daily, equivalent to about $7 \mathrm{~g} \mathrm{NaCl}$ for a $70 \mathrm{~kg}$ man. How do they do it? Their salvation lies in the fact that breast milk contains so much water as well as salt. The babies can deal with the salt because they take such a large volume of milk, and hence of water. I have said at a previous meeting of this Society (Widdowson, 1957) that a baby drinks about one-seventh of its own weight of water each day, which would correspond to I0 1. for a $70 \mathrm{~kg}$ man. By adding salt to the milk given to the babies we forced a relatively large amount of salt into them. The intake during the experimental period was 22 m-equiv. $/ \mathrm{kg} 24 \mathrm{~h}$, which is equivalent to $\mathrm{I} \cdot 43 \mathrm{~g} \mathrm{NaCl} / \mathrm{kg}$. For a $70 \mathrm{~kg}$ man this would come to $8 \mathrm{I} \mathrm{g}$, and the baby excreted half of its intake, equivalent to $47 \mathrm{~g}$ $\mathrm{NaCl} / 70 \mathrm{~kg}$ daily, so it did not do too badly. The half it failed to excrete, however, caused hypertonic expansion of the extracellular fluids and gave rise to oedema.

\section{Renal function and growth}

Not only do newborn babies and animals excrete less $\mathrm{Na}$ and $\mathrm{Cl}$ in a given volume of water than adults, but they also excrete less urea and other end-products of protein katabolism. Young babies have low urea clearances and glomerular filtration rates compared with adults (McCance \& Young, I940-I ; Young \& McCance, 1942), and this is true whether the comparison is made on a basis of surface area or of bodyweight (Table 2). This discovery led to an idea that the infant's kidneys were in-

Table 2. Urea and inulin clearance $(\mathrm{ml} / \mathrm{min})$ of newborn babies and adults

$\begin{array}{ccc}\text { Urea clearance: } & \begin{array}{c}\text { Per } \mathrm{I} \cdot 73 \mathrm{~m}^{2} \\ \text { surface area }\end{array} & \begin{array}{c}\text { Per } 70 \mathrm{~kg} \\ \text { body-weight }\end{array} \\ \text { Infant } & 17 & 42 \\ \text { Adult } & 75 & 75 \\ \text { Inulin clearance: } & & \\ \text { Infant } & 34 & 82 \\ \text { Adult } & 120 & 120\end{array}$


efficient and bordering even on the pathological. But the function of the kidneys at all ages is to maintain the constancy of the volume and composition of the body fluids, and this the kidneys of the newborn certainly do, so why should we condemn them as inefficient? It is true that the blood urea rises immediately after birth in many species, but it falls again very quickly while the baby or animal still has a very low urea clearance by adult standards. How does this apparent paradox come about?

Table 3 shows the nitrogen balances of piglets and puppies which were fed with sow's or bitch's milk by stomach tube for the first day or two of their lives (McCance $\&$ Widdowson, 1956, 1958) compared with those of piglets and puppies which had the same volume of water but no food. The animals given milk excreted only onetenth as much $\mathrm{N}$ in the urine as they took in in their food, and in fact they excreted very little more than litter-mates that received nothing but water, and that were breaking down some of their own tissue protein. The remaining nine-tenths of the protein and amino acids in the milk were used for purposes of growth.

\section{Table 3. Nitrogen balances of newborn piglets and puppies given milk or water by stomach tube}

$\begin{array}{lrrrr} & \overbrace{\text { Milk }}^{\text {Piglets given: }} & \text { Water } & \overbrace{\text { Milk }}^{\text {Puppies given: }} & \text { Water } \\ \mathrm{N} \text { intake }(\mathrm{mg} / \mathrm{kg} \mathrm{24} \mathrm{h}) & 3500 & \circ & 2500 & \circ \\ \mathrm{N} \text { output }(\mathrm{mg} / \mathrm{kg} \mathrm{24} \mathrm{h}) & 35^{\circ} & 25^{\circ} & 246 & 194 \\ \mathrm{~N} \text { balance }(\mathrm{mg} / \mathrm{kg} \mathrm{24} \mathrm{h}) & +315^{\circ} & -25^{\circ} & +2254 & -194\end{array}$

Piglets and puppies grow very rapidly and double their birth weight within the Ist week. Rapid growth is far more important than renal function in maintaining the serum urea within normal limits in these animals. The kidneys were perfectly well able to excrete nitrogenous end-products equivalent to $10 \%$ of the $\mathrm{N}$ intake and there was no appreciable rise in the blood urea.

The human baby grows very slowly compared with many mammals. Table 4 shows the $\mathrm{N}$ intakes and excretions of babies in the Ist week of life (McCance \& Widdowson, I954; Slater, I96I). On the Ist and 2nd days the babies had no food or water and katabolized some of their own tissue protein. Their kidneys did not excrete all the end-products of protein katabolism, possibly because they were short of water and their urine volumes small, and the level of urea in the body fluids rose. By the time they were I week old the breast-fed babies were taking in daily $400 \mathrm{mg} \mathrm{N} / \mathrm{kg}$ body-weight. They were absorbing about $80 \%$ of it, and retaining over $50 \%$ for purposes of growth. They were excreting in the urine an amount of $\mathrm{N}$ equivalent to $25 \%$ of the intake and, although this was more than they had been excreting when they were 2 days old, they were perfectly well able to do so with the amount of water available from the milk, and the level of urea in the blood fell again to a low level. If the urea clearances of these 7 -day-old breast-fed babies are calculated they appear very low by adult standards, as babies' clearances always do, but this in itself is no indication that their kidneys are inefficient. By the $7^{\text {th }}$ day of life the full-term breast-fed baby is dealing with twice as much protein per $\mathrm{kg}$ 
Table 4. Nitrogen balances of babies in the ist week of life

$\begin{array}{lcccc} & \text { Day I } & \text { Day 2 } & \text { Breast milk } & \begin{array}{c}\text { Cow's-milk } \\ \text { mixture }\end{array} \\ \mathrm{N} \text { intake }(\mathrm{mg} / \mathrm{kg} \mathrm{24} \mathrm{h}) & 0 & \circ & 397 & 598 \\ \mathrm{~N} \text { in urine }(\mathrm{mg} / \mathrm{kg} \mathrm{24} \mathrm{h}) & 40 & -0 & 117 & 22 \mathrm{I} \\ \mathrm{N} \text { in faeces }(\mathrm{mg} / \mathrm{kg} \mathrm{24} \mathrm{h}) & - & - & 67 & 73 \\ \mathrm{~N} \text { balance }(\mathrm{mg} / \mathrm{kg} \mathrm{24} \mathrm{h}) & -40 & -70 & +213 & +340 \\ \text { Blood urea }(\mathrm{mg} / \mathrm{I} 00 \mathrm{ml}) & 22.4 & 37.2 & 17.5 & 37.9\end{array}$

body-wejght as an adult having $100 \mathrm{~g}$ protein a day and his blood urea is falling, which all goes to show the vital importance of growth as a stabilizing agent for the internal environment at this time of life. The babies having the cow's-milk preparation had a higher $\mathrm{N}$ intake than the breast-fed babies. They retained a little more; they excreted twice as much, but the concentration of urea in their blood was higher. Natural selection has made mother's milk just about right for the successful integration of growth and renal function in each species. Cow's milk more than saturates a baby's growth requirements for protein, and conversely human milk does not support the growth requirements of fast-growing newborn rats.

\section{The effect of exposure to cold}

Babies born in very cold weather and left in rooms that are inadequately heated are sometimes admitted to hospital suffering from severe hypothermia, and it is possible that more than a hundred babies die because of this every year (Mann $\&$ Elliott, 1957). These babies feel cold and their body temperatures are generally below $90^{\circ} \mathrm{F}$, yet they may appear surprisingly well, with red face, hands and feet. The exposure to cold often gives rise to oedema. The babies are apathetic and unwilling to take food and they sometimes have blood sugar levels low enough to cause convulsions.

Once again, we have used newborn piglets to study this problem experimentally (McCance \& Widdowson, I959). Indeed, cold is a hazard to piglets born in the winter as well as to babies, and piglets also may die of hypoglycaemia (Goodwin, 1957). Piglets were removed from the sow as they were born. One or two were killed at once, and the others were divided into two groups. Half of them were put in a cool chamber at $12^{\circ}$ and the others in a warm one at $31^{\circ}$. The piglets were kept under observation at these temperatures for $24 \mathrm{~h}$, but they were given no food or water. At an ambient temperature of $3^{\circ}$ the animals remained lively and alert for the whole $24 \mathrm{~h}$ - they will do so for at least $48 \mathrm{~h}$-and they maintained their blood sugar levels and body temperatures within normal limits.

At $12^{\circ}$ the animals exhibited reasonably normal deep-body temperatures for 8-I 2 h, but after that the rectal temperatures began to fall, and they fell progressively faster until by about $24 \mathrm{~h}$ they were generally $20-22^{\circ}$ (about $70^{\circ} \mathrm{F}$ ) and the animals were in extremis, lying in the cage, making rather characteristic feeble cycling movements with their legs. Yet they, like the babies, looked pink, and like the babies 
also they became oedematous, which was very noticeable on the side on which they had been lying, for the pattern of the bottom of the cage was deeply imprinted on the skin. Table 5 shows that the blood sugar levels were very low, and sometimes these piglets had convulsions, particularly if they were warmed up with the idea of resuscitating them.

Table 5. Effect of warm and cold surroundings on the breakdown of tissue protein and on the concentration of carbohydrate in the tissues of starving newborn piglets

Water in body (g/100 g)

Nitrogen appearing in end-products of protein katabolism (mg/kg $24 \mathrm{~h}$ )

Blood sugar $(\mathrm{mg} / 100 \mathrm{ml})$

Liver glycogen $(\mathrm{g} / 100 \mathrm{~g})$

Muscle glycogen $(\mathrm{g} / \mathrm{1} 00 \mathrm{~g})$

At birth
$8 \mathrm{r} \cdot 2$


95
$8 \cdot 5$
$7 \cdot 2$

Starved for $24 \mathrm{~h}$

$\begin{array}{cc}\text { Warm }\left(3 x^{\circ}\right) & \text { Cold }\left(12^{\circ}\right) \\ 81 \cdot 2 & 83 \cdot 2 \\ 70 & 280\end{array}$

$\begin{array}{cc}93 & 14 \\ 5 \cdot 1 & 1 \cdot 0 \\ 5 \cdot 2 & 0.4\end{array}$

Piglets are born with almost no fat in their bodies but with high concentrations of glycogen in their livers and skeletal muscles. This glycogen had largely disappeared in the animals exposed to cold, presumably because the carbohydrate had been metabolized when the metabolic rate had been raised and held at a high level during the first 8- $12 \mathrm{~h}$. The breakdown of tissue protein was also far greater in the cold than in the warm.

The percentage of water in the body of a newborn piglet is about $8 \mathrm{r}$, and it did not change appreciably after $24 \mathrm{~h}$ without any food or water in a warm environment. At $12^{\circ}$, however, it increased, although the animals had had no water by mouth. Table 6 shows how this came about. When a piglet is starved and given no water, and kept in a warm environment, solids and water are lost from the body in approximately the proportions in which they were originally present, and the percentage of water in the body does not change. When a piglet is exposed to cold, its rate of metabolism is increased, and considerably more solids, mostly carbohydrate, are used up, but the water previously associated with the carbohydrate and formed in the course of its metabolism is not excreted. Consequently the percentage of water in the animal is higher after deprivation of water for $24 \mathrm{~h}$ than it was at the beginning. This explains the oedema at the end of the experiment, and it may also explain why babies suffering from cold injury have been found to be oedematous.

Table 6. Effect of warm and cold surroundings on the composition of the weight loss of piglets during 24 h of starvation and deprivation of water

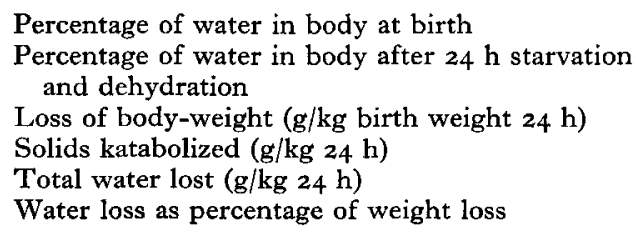

Percentage of water in body at birth

Percentage of water in body after $24 \mathrm{~h}$ starvation and dehydration

Loss of body-weight ( $\mathrm{g} / \mathrm{kg}$ birth weight $24 \mathrm{~h}$ )

Solids katabolized $(\mathrm{g} / \mathrm{kg} 24 \mathrm{~h})$

Total water lost $(\mathrm{g} / \mathrm{kg} 24 \mathrm{~h})$

Water loss as percentage of weight loss

$\begin{array}{cc}\text { Warm }\left(3 \mathrm{I}^{\circ}\right) & \text { Cold }\left(12^{\circ}\right) \\ 8 \mathrm{I} \cdot 2 & 8 \mathrm{I} \cdot 2 \\ 8 \mathrm{I} \cdot 2 & 83 \cdot 2 \\ & \\ 89 & 98 \\ 17 & 35 \\ 72 & 63 \\ 8 \mathrm{I} & 65\end{array}$




\section{Respiratory distress}

Babies born prematurely are particularly liable to suffer from what is known as 'the respiratory distress syndrome' or 'hyaline membrane disease'. Exactly what is the nature and source of the material covering the finer air spaces of the lungs and causing this disease is still controversial, but it creates great difficulty in breathing and the babies have to work very hard for their oxygen requirements, and their respiration is laboured and gasping. Anything which puts up the metabolic rate might be expected to cause an increase in the breakdown of body solids, and it has been shown (Nicolopoulos \& Smith, I960; Usher, I960) that in these infants an abnormally large amount of tissue protein is katabolized. It is known, moreover, that babies suffering from respiratory distress are often oedematous.

We have recently succeeded in producing a form of respiratory distress in newborn piglets by keeping them in an atmosphere containing $8 \%$ oxygen and $10 \%$ carbon dioxide (Glauser, McCance \& Widdowson, 1962). The animals were kept at an environmental temperature of about $3 \mathrm{r}^{\circ}$ for $24 \mathrm{~h}$. At its maximum the respiratory rate was $100 / \mathrm{min}$ or even more, as compared with the normal 20-30. Table 7 shows the effect of respiratory distress brought about in this way on the concentration of carbohydrate in the tissues, on the katabolism of tissue protein and on the percentage of water in the bodies. The breakdown of tissue protein was approximately doubled, but the breakdown of carbohydrate in the body as a whole was much less affected by the respiratory effort than it was by exposure to cold. The concentration of glycogen in the diaphragm, however, fell to less than half its original level.

Table 7. Effect of 'respiratory distress' on the percentage of water in the body, on the breakdown of tissue protein and on the blood sugar level of starving newborn piglets

Water in body $(\mathrm{g} / 100 \mathrm{~g})$

$\mathrm{N}$ appearing in end-products of protein katabolism $(\mathrm{mg} / \mathrm{kg} 24 \mathrm{~h})$

Blood sugar $(\mathrm{mg} / \mathrm{r} 00 \mathrm{ml})$

Muscle glycogen $(\mathrm{g} / \mathrm{1} 00 \mathrm{~g})$

Diaphragm glycogen $(\mathrm{g} / \mathrm{/} / 0 \mathrm{~g})$

\begin{tabular}{ccc} 
& \multicolumn{2}{c}{ Starved for $24 \mathrm{~h}$} \\
At low \\
At birth & In air & $\mathrm{O}_{2}$ tension \\
$82 \cdot \mathrm{I}$ & $8 \mathrm{I} \cdot 8$ & $8 \mathrm{I} \cdot 6$ \\
& 49 & $24 \mathrm{I}$ \\
93 & 76 & 68 \\
6.0 & 5.9 & 5.7 \\
6.0 & 5.3 & 2.5
\end{tabular}

There was an increased breakdown of body solids in the overbreathing piglets, but it was less than in the piglets exposed to cold, and the proportion of water in the bodies did not change. This effect may have been due to a large loss of water through the lungs, due to the overbreathing. Since infants suffering from hyaline membrane disease do not overbreathe in this way there is not the same loss of water through the lungs. An increased breakdown of body solids without correspondingly high loss of water may in fact be the cause of their oedema.

\section{Conclusion}

We have chosen the newborn piglet for many of our investigations because in many ways it resembles the newborn baby. It is, moreover, of a convenient size, 
and it grows very rapidly, which for some purposes is a great advantage. The large litters are useful, for they provide plenty of animals for experimental purposes and for controls.

'La solution d'un problème physiologique ou pathologique résulte uniquement d'un choix plus convenable du sujet de l'expérience, qui rend le résultat plus clair ou plus probant' (Bernard, I865). I think our choice of the pig has on the whole been a happy one.

\section{REFERENCES}

Bernard, M. C. (I865). Introduction à l'Étude de la Médicine Expérimentale. Paris: J. B. Baillière et Fils. Edwards, W. F. (1824). De l'Influence des Agents Physiques sur la Vie. Paris: Crochard.

Edwards, W. F. (1832). On the Influence of Physical Agents on Life. (Translated from the French by Dr Hodgkin and Dr Fisher.) London: Highley.

Glauser, E. M., McCance, R. A. \& Widdowson, E. M. (1962). F. Physiol. r6r, 3 I 3.

Goodwin, R. F. W. (1957). F. Physiol. 136, 208.

Harvey, W. (165I). De Generatione Animalium. Translated by Willis, R. (1847). The Works of William Harvey. London: Sydenham Society.

McCance, R. A. \& Widdowson, E. M. (1954). Arch. Dis. Childh. 29, 488.

McCance, R. A. \& Widdowson, E. M. (1956). F. Physiol. r33, 373.

McCance, R. A. \& Widdowson, E. M. (1957). Acta paediat., Uppsala, 46, 337.

McCance, R. A. \& Widdowson, E. M. (1958). F. Physiol. 14r, 8r.

McCance, R. A. \& Widdowson, E. M. (1959). F. Physiol. 147, 124.

McCance, R. A. \& Young, W. F. (1940-1). J. Physiol. 99, 265.

Mann, T. P. \& Elliott, R. I. K. (I957). Lancet, i, 229.

Mayow, J. (r668). Quoted by Parsons (1950).

Nicolopoulos, D. A. \& Smith, C. A. (r960). Amer. F. Dis. Child. roo, 6rg.

Parsons, L. (1950). The Influence of Harvey and his Contemporaries on Paediatrics. The Harveian Oration, 1950. London: Headley Brothers Ltd.

Slater, J. E. (1961). Brit. F. Nutr. 15,83.

Usher, R. H. (1960). Amer. F. Dis. Child. roo, 485 .

Widdowson, E. M. (1957). Proc. Nutr. Soc. r6, i 18.

Young, W. F. \& McCance, R. A. (1942). Arch. Dis. Childh. 17, 65.

\section{Is a big baby healthy?}

\section{By R. C. Mac KeIth, Guy's Hospital, London, S.E.x}

'An adequate understanding is necessary of the way in which habitual diet may determine in part the development of constitution in an individual since such an understanding underlies an approach to the consideration of some diseases of multiple and uncertain aetiology developing in middle life. This group of diseases includes such important degenerative diseases as atherosclerosis, cancer and hypertension. At earlier ages it may include such disorders as allergy, anaphylaxis and the rheumatic, rheumatoid and collagen disorders. The claim is not lightly made. All will agree that the diseases mentioned are of uncertain and probably multiple aetiology and that they have their roots both in the genetic make-up of the individual and in the long term effects of environmental stresses. Among these stresses we must surely include dietary malnutrition, using the term in its broadest sense to include deficiency, excess or imbalance of nutrients' (Brock, I96r).

With this in mind, let us consider, for example, the commonest cause of repeated absence of older children from school. This is asthma, and asthma and the related 